\title{
Review on: The Effect of Mixing Organic and Inorganic Fertilizer on Productivity and Soil Fertility
}

\author{
Tesfaye Burju Roba \\ Department of Biology, Robe Teachers College, Robe, Ethiopia \\ Email: tesfayeburju@yahoo.com
}

How to cite this paper: Roba, T.B. (2018) Review on: The Effect of Mixing Organic and Inorganic Fertilizer on Productivity and Soil Fertility. Open Access Library Journal, 5: e4618.

https://doi.org/10.4236/oalib.1104618

Received: April 24, 2018

Accepted: June 23, 2018

Published: June 26, 2018

Copyright $\odot 2018$ by author and Open Access Library Inc.

This work is licensed under the Creative Commons Attribution International License (CC BY 4.0).

http://creativecommons.org/licenses/by/4.0/

\section{(c) (i) Open Access}

\begin{abstract}
Depletion of soil fertility is a main problem to sustain agricultural production and productivity in many countries. The use of inorganic or organic fertilizer alone has both positive and negative effects on plant growth, nutrient availability and the soil. Organic fertilizer improves physical and biological activities of soil but they have comparatively low in nutrient content, so larger quantity is required for plant growth. However, inorganic fertilizer is usually immediately and fast containing all necessary nutrients that are directly accessible for plants. But continuous use of inorganic fertilizers alone causes soil organic matter: degradation, soil acidity and environmental pollution. So the integrated nutrient management system is an alternative system for the sustainable and cost-effective management of soil fertility by combined apply of inorganic with organic materials resulting in rising soil fertility and productivity without affecting environment. The objective of the present review is to assess the effect of mixing organic with inorganic fertilizer on soil fertility and productivity. The study revealed that appropriate application of organic with inorganic fertilizers increases the productivity without negative effect on yield quality and improves soil fertility than the values obtained by organic or inorganic fertilizers separately.
\end{abstract}

\section{Subject Areas}

Soil Science

\section{Keywords}

Soil, Organic Fertilizer, Inorganic Fertilize, Integrated Nutrient Management

\section{Introduction}

The sustainable crop cultivation needs appropriate treatment of nutrient re- 
sources and conservation of soil fertility. But depletion of soil fertility is a main problem to sustain agricultural production and productivity in many countries. Soil fertility is defined as the capacity of a soil to supply nutrients in adequate amounts and in proper balance for sustainable biological productivity, maintain environmental quality and promote plant and animal health [1] [2]. One of the most important nutrient input sources into the soil is fertilizer. Fertilizer is organic or inorganic that supplies plants with the necessary nutrients for plant growth and maximum yield [3].

Cultivated soils do not usually have sufficient amounts of plant nutrients for high and sustained productivity yields [4], due to soil degradation, soil acidification, soil organic matter reduction and decrease the aggregate stability of soil [5]. Continuous cultivation has also been observed to cause considerable decline in soil $\mathrm{pH}$ and exchangeable $\mathrm{Ca}$ and $\mathrm{Mg}$ levels in soils. Therefore, soil degradation, changes in soil quality that result from wind and water erosion and losses of organic matter are of big concern in every agricultural area in the world [6].

Emerging facts illustrated that combined application of organic and inorganic fertilizers increases the productivity like Maize, wheat, rice, apple and tomato [13] [14] [15] [16] [17] without negative effect on crop and fruit quality [12] [16] and improves soil fertility through increasing plant residues than the values obtained by organic or inorganic fertilizers separately.

The integrated nutrient management system is an alternative and is characterized by reduced input of inorganic fertilizers and combined use of inorganic fertilizers with organic materials such as animal manures, crop residues, green manure and composts [7] [8]. Combined use of organic and inorganic fertilizers plays a significant role in sustaining soil fertility [9] [10] [11] and the use of organic fertilizers together with inorganic fertilizers, has a higher positive effect on microbial biomass and enhances soil health [10] and improves the use efficiency of recommended inorganic fertilizer and reduces its cost [9] [12].

\section{Objective of Review}

- To identify the advantage and disadvantage of organic and inorganic fertilize on productivity and soil fertility as well as on environment.

- To review the effect of mixing organic and inorganic fertilizer on productivity and soil fertility.

\section{Fertilizer}

\subsection{Organic Fertilizer}

Organic fertilizers are natural materials of either plant or animal source, including livestock manure, green manures, crop residues, household waste, compost, and works directly as a source of plant nutrients and indirectly influences the physical, biological and chemical properties of soil [18] [19]. Microorganisms from the soil decay the organic fertilizer to make its nutrients available for utilize by plants [13] which added into the soil and have the characteristic nature of slow release of nutrients. 


\subsubsection{Advantages of Organic Fertilizer}

Organic fertilizers have the following advantages to improve soil fertility: increasing organic matter in soil which improves the soil structure, creating more air space and water retention within the soil and enhances soil nitrogen content, enhanced nutrient availability, releasing nutrients at a slower and more consistent rate, improves nutrient mobilization and Protect the soil against rain and wind erosion [20] [21] [22] [23] [24].

Organic fertilizer enhances soil biological activity and the colonization of mycorrhizae. That enhances mutuality association between fungi and higher plants. Organic fertilizer increase root growth due to enhanced soil structure, promoting soil aggregates, enhances cation exchange capacity [21]. Organic fertilizer acts as a buffering agent against undesirable soil pH fluctuations [19] [25].

\subsubsection{Disadvantages of Organic Fertilizer}

Potentially Pathogenic: improperly-processed organic fertilizers may contain pathogens that are harmful to humans or plants because organic fertilizers are derived from substance like animal feces or plant/animal matter contaminated with pathogens [8] [26].

Limited Nutrient Availability: they are relatively low in nutrient content, so larger volume is needed to supply enough nutrients for plant growth. Hence, large-scale agriculture without use inorganic fertilizers it is difficult [11].

Accurate Application: due to composition of organic fertilizers highly variable, so that accurate application of nutrients to match plant production is difficult. Also Microorganisms are required to break down and release nutrients into the soil. They need warmth and moisture to do their job, the effectiveness of organic fertilizer is limited seasonally [8] [26].

\subsection{Why Inorganic Fertilizer?}

Several researchers have demonstrated that organic soil decreased by many factors. Nutrients like nitrogen, potassium and phosphorus are removed by livestock through grazing and crop residue collection. Nutrients consumed by the livestock are recovered through byproducts such as manure. However, the manure is not allowed to recycle back to the farming and grazing lands, due to its alternative uses as fuel. For instance in Ethiopian about 22.5 million tons of cattle manure annually produced, out of this $38 \%$ is used as a fuel and 21.2 million tons of crop residues annually produced, $24 \%$ is used as a fuel. The remaining $76 \%$ of crop residue is used by livestock and/or left on the ground [27]. This leads to degradation of soils which has low nutrients. For soil that much deteriorated, adding of chemical fertilizers might be essential because chemical fertilizers can re-establish the soil fertility very quickly and the nutrients are obtainable to the plants as soon as the fertilizers are dissolved in the soil [22]. Inorganic fertilizer increases root residues that mean indirectly increases organic matter [28]. Due to this recently farmers put an emphasis on chemical fertilizer application in order to increase the productivity [19]. 


\subsubsection{Advantages of Inorganic Fertilizer}

Inorganic fertilizers are good for rapid growth of plants because the nutrients are already water soluble. Therefore the effect is usually immediately and fast, contains all necessary nutrients that are ready to use. Inorganic fertilizers are quite high in nutrient content and only relatively small amounts are required for productivity. Correct amount applications of inorganic fertilizer can increase soil organic matter through higher levels of root mass and crop residues [8] [24] [26] [28].

\subsubsection{Disadvantages of Inorganic Fertilizer}

Over-application can result in negative effects such as leaching, pollution of water, acidification and reduces the availability of the trace element or alkalization of the soil. Chemical fertilizer enhances the decomposition of soil organic matter, which leads to degradation of soil structure and decrease in soil aggregation results in nutrients are easily lost from soils through fixation, leaching, gas emission and can lead to diminish fertilizer efficiency [3] [8] [26] [29] [30].

Over treatments of chemical fertilizers can destroy decomposers and other soil organisms, reduce the colonization of plant roots with mycorrhizae and inhibit symbiotic N-fixation by rhizobia due to high N-fertilization [8] [12] [26] [31] and also hazardous to the soil environment. This showed that over treatments Chemical fertilizer causes problems not only to the soil health but also to the human health and physical environment.

\section{The Effect of Mixing Organic and Inorganic Fertilizer on Productivity and Soil Fertility}

\subsection{Why Integrated Soil Fertility Management?}

Sustaining soil fertility and increasing productivity using organic resources alone would be required large amount of organic fertilizer to maintain soil fertility levels in each and every field. However, the opposite strategy, the use of inorganic fertilizers alone may lead to high crop yields in the short period of time. But it affects soil structure which leads to decline of organic matter and environmental pollution [8] [26].

The problems associated with the single approach application of organic or inorganic fertilizers have made a combination of organic and inorganic fertilizers a realistic option in improving soil fertility and productivity. So the best ways for soil fertility is, therefore, integration of both inorganic and organic fertilizers to increases soil productivity as well as soil fertility [23] [32] by less expensive ways [23] [33] and decreases the damage that can be induced by chemical fertilizers [24].

\subsection{Experimental Results on the Effect of Mixing Organic Fertilizer with Inorganic Fertilizer on Productivity and Soil Fertility}

\subsubsection{Maize}

A study by [14] showed that mixed use of organic with inorganic fertilizers 
significantly $(\mathrm{p}<0.05)$ increased maize yield than individual use of organic or inorganic fertilizer [34]. Also conducted that the integrated use of poultry manure along with NPK fertilizer was more successful in rising nutrient availability and maize yield than sole application of any of the fertilizer materials on sandy soil, loam texture with high proportion of coarse sand (84\%). Similarly, [35] reported that integrated use of inorganic fertilizer along with organic fertilizer $(100 \%$ NPK + FYM) was improved soil physical conditions and increased in soil organic carbon might have resulted in higher maize yields. Finding of several researchers showed that integrated use of chemical and organic fertilizer has proved to be significantly increases maize productivity [36] [37] [38].

\subsubsection{Rice}

[15] carried out an experiment on the "Combined Effect of Organic Manures and Inorganic Fertilizers on the Growth and Yield of Hybrid Rice". The result showed that the integrated application of organic manures with inorganic fertilizers was effective in enhancing growth and yield of hybrid rice. These outcomes have the great potential for reducing the use of chemical fertilizers without decreasing the yield of hybrid rice [39] Conducted research on the "Effects of Integrated use of Organic and Inorganic Fertilizers on Soil Properties Performance, using Rice (Oryza sativa L.)". The results showed that the integrated use of organic manure with inorganic fertilizers not only increased the rice yield but also improved the fertility status of the soil than inorganic fertilizers alone. Experimental studies on rice by [40] showed that for improvement rice productivity, mixed use of synthetic $\mathrm{N}$ with organic $\mathrm{N}$ sources is needed to be practiced. Similarly, many authors have suggested that rice productivity was significantly raised by the combined application of organic with inorganic fertilizes [9] [23] [41].

\subsubsection{Wheat}

[42] conducted research on the "Evaluation of Synergistic Effect Organic and Inorganic Fertilizing System on Grain Yield of Bread Wheat (Triticum aestivum L.) at Southern Tigray, Northern Ethiopia". The outcome showed that the incorporated use of farmyard manure with $\mathrm{N}$ and $\mathrm{P}$ fertilizers are efficient than the use of either N/P or farmyard manure alone. Similar result was reported by [43] that the incorporated application of organic with inorganic fertilizers enhanced yield of wheat as well as soil fertility. [44] Reported that application of NPK with poultry manure significantly increased wheat productivity. Several investigators have concluded that combined use inorganic fertilizer with organic materials perform better in terms of improving productivity and yields of wheat [20] [35] [45].

\subsubsection{Tomato}

A study by [46] showed that the use of mixed NPK fertilizer along with poultry 
manure was more effective for tomato cultivation. Similarly [47] reported that the mixed use of organic with inorganic fertilizers significantly $(\mathrm{p} \leq 0.05)$ increased total number of collected tomato and weight of harvest. According [16] mixed fertilizer (organic+ inorganic) created the highest amount of flower clusters (31.2), fruit clusters (24.9), fruit yield $(15.3 \mathrm{t} / \mathrm{ha})$ and plant height $(71.6 \mathrm{~cm})$ than to the no fertilizer application. The result showed that the effect of mixed fertilizers on tomato yield was significantly $(\mathrm{p}<0.01)$ higher yields than the control (no fertilizer application). [48] conducted an experiment on the "Effect of compost and inorganic fertilizers on yield and quality of tomato" the result showed the yield and quality parameters of tomato fruit increased significantly $(\mathrm{P} \leq 0.05)$ by mixed use of compost with inorganic fertilizers. Also the study by [49] showed that use of inorganic and organic fertilizer had better results on tomato productivity.

\subsubsection{Apple}

[17] conducted an experiment on the "Effects of Chemical Fertilizer Combined with Organic Manure on Fuji Apple Quality, Yield and Soil Fertility in Apple orchard on the Loess Plateau of Chin". The outcome showed that the average annual yield followed the sequence of inorganic fertilizer (NPK) + Manure (36.9 t/ha) $>$ NPK $(35.4 \mathrm{t} / \mathrm{ha})>$ Manure $(34.9 \mathrm{t} / \mathrm{ha})>\mathrm{NK}(28.5 \mathrm{t} / \mathrm{ha})>\mathrm{NP}(27.9$ $\mathrm{t} / \mathrm{ha})>\mathrm{PK}(25.9 \mathrm{t} / \mathrm{ha})$. It was concluded that the continuous application of organic manure plus balanced fertilization with $\mathrm{N}, \mathrm{P}$ and $\mathrm{K}$ for five years significantly increased apple yield and improved apple quality.

\subsection{Soil Fertility}

Soil fertility: A study by [35] showed that integrated use of inorganic fertilizer along with organic fertilizer (100\% NPK + FYM) improved soil physical conditions such as $\mathrm{CEC}$ and $\mathrm{pH}$ resulted in higher maize and wheat yields. According to [24] the NPK fertilizer treatment leads to soil acidification, whereas organic manure + NPK treatments significantly increased soil $\mathrm{pH}$. Similar type findings was reported by [50] that the incorporated nutrient management system results in rising organic carbon content, available nitrogen, phosphorus and potassium increasing from $0.390 \%$ to $0.543 \%, 171.7$ to $219.3 \mathrm{~kg} \cdot \mathrm{ha}^{-1}$ and 20.5 to $43.3 \mathrm{~kg} \cdot \mathrm{ha}^{-1}$ respectively.

Several studies revealed that the integrated use of inorganic fertilizer with organic fertilizer like manure significantly $(\mathrm{P}<0.05)$ increases soil organic $\mathrm{C}$ content, total N, and the available soil nutrients [9] [17] [39] improves the overall soil properties [14]. For sustainable productivity, mixed use of chemical with organic fertilizer has proved to be highly beneficial in terms of balanced nutrient supply [8] [34] and significantly higher than yields from sole organic fertilizer application [36]. Also the use of organic fertilizers together with appropriate chemical fertilizers, had a higher positive effect on microbial biomass and hence soil health [10] [12] [51]. 


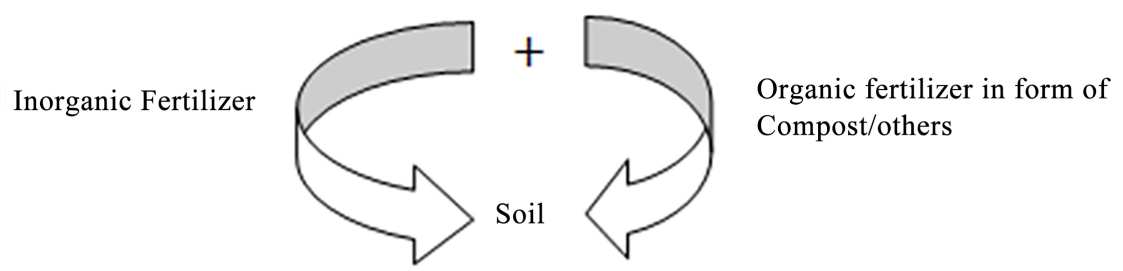

Best management system for increasing soil fertility

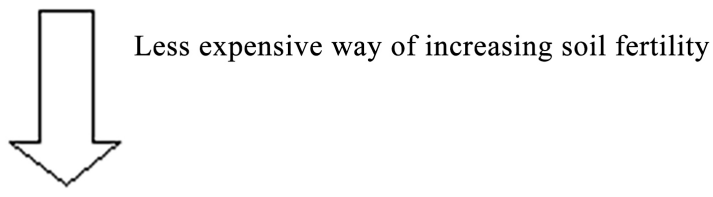

High Productivity

effect of mixing organic and inorganic fertilizer on soil fertility and productivity

\section{Conclusion}

This review showed that, continuous cultivation and low nutrient application are the main reason of declining soil fertility. In various cases, the loss of organic matter results in reducing physical, biological and functional properties of soil. Organic fertilizers have more benefits in the long run compared to inorganic fertilizers. Organic fertilizer improves physical, biological, and chemical properties of a soil but the nutrients may not be as readily available to the plants. However, inorganic fertilizer is usually immediately and fast containing all necessary nutrients that are ready for plants. The excess use of inorganic fertilizers in agriculture can lead to soil deterioration, soil acidification and environment pollution. The integrated soil fertility management system is an alternative approach for the sustainable and cost-effective management of soil fertility and is characterized by reduced input of inorganic fertilizers and combined use of inorganic fertilizers with organic materials. Combined applications of organic and inorganic fertilizers improve soil fertility, productivity and reduce the impact of inorganic fertilizer on environment. So, it is an alternative way for sustainable soil fertility and productivity.

\section{References}

[1] Hartemink, A.E. (2006) Soil Fertility Decline: Definitions and Assessment. In: Encyclopedia of Soil Science, Taylor and Francis, New York, 1618-1621.

[2] Karlen, D., Andrews, S., Wienhold, B. and Obeck, T. (2008) Soil Quality Assessment: Past, Present and Future. Journal of integrative Bioscience, 6, 3-14.

[3] Alimi, T., Ajewole, O.C., Awosola, O. and Idowu, E.O. (2007) Organic and Inorganic Fertilizer for Vegetable Production under Tropical Conditions. Journal of Agricultural and Rural Development, 1, 120-136.

[4] Quansah, G.W. (2010) Effect of Organic and Inorganic Fertilizers and Their Combinations on the Growth and Yield of Maize in the Semi-Deciduous Forest Zone of Ghana. Kwame Nkrumah University of Science and Technology, Kumasi, Ghana.

[5] Meyer, A.D., Poesen, J., Isabirye, M., Deckers, J. and Rates, D. (2011) Soil Erosion Rate in Tropical Villages: A Case Study from Lake Victoria Basin, Uganda. Catena, 
84, 89-98. https://doi.org/10.1016/j.catena.2010.10.001

[6] Liu, X., Herbert, S.J., Hashemi, A.M., Zhang, X. and Ding, G. (2006) Effects of Agricultural Management on Soil Organic Matter and Carbon Transformation. Plant Soil Environment, 12, 531-543.

[7] Negassa, W., Getaneh, F., Deressa, A. and Dinsa, B. (2007) Integrated Use of Organic and Inorganic Fertilizers for Maize Production. Witzenhausen, Germany.

[8] Chen, J.H. (2008) The Combined Use of Chemical and Organic Fertilizers and/or Biofertilizer for Crop Growth and Soil Fertility. Taichung, Taiwan.

[9] Ali, M.E., Islam, M.R. and Jahiruddin, M. (2009) Effect of Integrated Use of Organic Manures with Chemical Fertilizers in the Rice-Rice Cropping System and Its Impact on Soil Health. Bangladesh Journal of Agricultural Sciences, 34, 81-90.

[10] Elkholy, M.M., Samira, E., Mahrous and El-Tohamy, S.A. (2010) Integrated Effect of Mineral, Compost and Biofertilizers on Soil Fertility and Tested Crops Productivity. Research Journal of Agriculture and Biological Sciences, 5, 453-465.

[11] Vanlauwe, B., Bationo, A., Chianu, J., Giller, K.E., Merckx, R., Mokwunye, U., Ohiokpeh, O., Pypers, P., Tabo, R., Shepherd, K., Smaling, E. and Woomer, P. (2010) Integrated Soil Fertility Management: Operational Definition and Consequences for Implementation and Dissemination. Outlook on Agriculture, 39, 17-24. https://doi.org/10.5367/000000010791169998

[12] Abedi, T., Alemzadeh, A. and Kazemeini, S. (2010) Effect of Organic and Inorganic Fertilizers on Grain Yield and Protein Banding Pattern of Wheat. Austarlian Journal of Crop Science, 4, 384-389.

[13] Amujoyegbe, B.J., Opabode, J.T. and Olayinka, A. (2007) Effect of Organic and Inorganic Fertilizer on Yield and Chlorophyll Content of Maize (Zea mays L.) and Sorghum Sorghum bicolor (L.) Moench. African Journal of Biotechnology, 6, 1869-1873. https://doi.org/10.5897/AJB2007.000-2278

[14] Mahmood, F., Khan, I., Ashraf, U., Shahzad, T., Hussain, S., Shahid, M., Abid, M. and Ullah, S. (2017) Effects of Organic and Inorganic Manures on Maize and Their Residual Impact on Soil Physico-Chemical Properties. Journal of Soil Science and Plant Nutrition, 17, 22-22. https://doi.org/10.4067/S0718-95162017005000002

[15] Moe, K., Win, M.K., Win, K.K. and Yamakawa, T. (2017) Combined Effect of Organic Manures and Inorganic Fertilizers on the Growth and Yield of Hybrid Rice (Palethwe-1). American Journal of Plant Sciences, 8, 1022-1042. https://doi.org/10.4236/ajps.2017.85068

[16] Islam, M.A., Islam, S., Ayasha, A., Md Habibur, R. and Dilip, N. (2017) Effect of Organic and Inorganic Fertilizers on Soil Properties and the Growth, Yield and Quality of Tomato in Mymensingh, Bangladesh. Agriculture, 7, 18.

[17] Zhao, Z., Yan, S., Liu, F., Ji, P., Wang, X. and Tong, Y. (2014) Effects of Chemical Fertilizer Combined With Organic Manure on Fuji Apple Quality, Yield and Soil Fertility in Apple Orchard on the Loess Plateau of China. International Journal of Agriculture and Bioengineering, 7, 45-55.

[18] Ngoc Son, T., Thu, V., Hong Man, L., Kobayashi, H. and Yamada, R. (2004) Effect of Long-Term Application of Organic and Biofertilizer on Soil Fertility under Rice-Soybea Rice Cropping System. OmonRice, 12, 45-51.

[19] Basel, N. and Sami, M. (2014) Effect of Organic and Inorganic Fertilizers Application on Soil and Cucumber (Cucumis sativa L.) Plant Productivity. International Journal of Agriculture and Forestry, 4, 166-170.

[20] Akhtar, M.J., Asghar, H.N., Shahzad, K. and Arshad, M. (2009) Role of Plant 
Growth Promoting Rhizobacteria Applied in Combination with Compost and Mineral Fertilizers to Improve Growth and Yield of Wheat (Triticum aestivum). Pakistan Journal of Botany, 41, 381-390.

[21] Lal, R. (2006) Enhancing Crop Yields in the Developing Countries through Restoration of the Soil Organic Carbon Pool in Agricultural Lands. Land Degradation \& Development, 17, 197-207. https://doi.org/10.1002/ldr.696

[22] Matsumoto, T. and Yamano, T. (2009) Soil Fertility, Fertilizer and the Maize Green Revolution in East Africa. Policy Working Paper, WPS5158, Japan's National Graduate Institute for Policy Studies and the World Bank Development Research Group Agriculture and Rural Development.

[23] Nyalemegbe, K.K., Oteng, J.W. and Brempong, S.A. (2009) Integrated Organic-Inorganic Fertilizer Management for Rice Production on the Vertisols of the Accra Plains of Ghana. West Africa Journal of Applied Ecology, 16, 23-33.

[24] Han, S.H., Young, J., Hwang, J., Kima, S.B. and Parka, B. (2016) the Effects of Organic Manure and Chemical Fertilizer on the Growth and Nutrient Concentrations of Yellow Poplar (Liriodendron tulipifera Lin.) in a Nursery System. Forest Science and Technology, 12, 137-143. https://doi.org/10.1080/21580103.2015.1135827

[25] Olaniyi, J.O. and Ajibola, A. (2008) Effects of Inorganic and Organic Fertilizers Application on the Growth, Fruit Yield and Quality of Tomato (Lycopersicon lycopersicum). Journal of Applied Biosciences, 8, 236-242.

[26] GTZ (2009) Food Crisis and Land: The World Food Crisis, Land Degradation and Sustainable Land Management: Linkages, Opportunities and Constraints.

[27] Erkossa, T., Stahr, K. and Tabor, G. (2004) Integration of Organic and Inorganic Fertilizers: Effect on Vegetable Productivity. Soil Science and Land Evaluation, Debre Zeit Agricultural Research Centre, Ethiopia.

[28] Scholl, L. and Nieuwenhuis, R. (2004) Soil Fertility Management. Agromisa Foundation, Wageningen, Netherlands.

[29] Savci, S. (2012) Investigation of Effect of Chemical Fertilizers on Environment. APCBEE Procedia, 1, 287-292. https://www.sciencedirect.com/

[30] Adediran, J.A., Taiwa, L.B., Akande, M.O., Sobulo, R.A. and Idown, O.J. (2004) Application of Organic and Inorganic Fertilizer for Sustainable Maize and Cowpea Yield in Nigeria. Journal of Plant Nutrition, 27, 1163-1181. https://doi.org/10.1081/PLN-120038542

[31] Gruhn, P., Goletti, F. and Yudelman, M. (2000) Integrated Nutrient Management, Soil Fertility and Sustainable Agriculture: Current Issues and Future Challenges. International Food Policy Research Institute, Washington DC, USA.

[32] Bodruzzaman, M., Meisner, C.A., Sadat, M.A. and Hossain, M.I. (2010) Long-Term Effects of Applied Organic Manures and Inorganic Fertilizers on Yield and Soil Fertility in a heat-Rice Cropping Pattern. Brisbane, Australia.

[33] Mungai, N.W., Bationo, A. and Waswa, B. (2009) Soil Properties as Influenced by Soil Fertility Management in Small Scale Maize Farms in Njoro, Kenya. Journal of Agronomy, 4, 131-136. https://doi.org/10.3923/ja.2009.131.136

[34] Ayeni, L.S. and Adetunji, M.T. (2010) Integrated Application of Poultry Manure and Mineral Fertilizer on Soil Chemical Properties, Nutrient Uptake, Yield and Growth Components of Maize. Nature and Science, 8, 60-67.

[35] Brar, B.S., Singh, J., Singh, G. and Kaur, G. (2015) Effects of Long Term Application of Inorganic and Organic Fertilizers on Soil Organic Carbon and Physical Properties in Maize-Wheat Rotation. Agronomy, 5, 220-238. 
[36] Efthimiadou, A., Bilalis, D., Karkanis, A. and Williams, B.F. (2010) Combined Organic/Inorganic Fertilization Enhances Soil Quality and Increased Yield, Photosynthesis and Sustainability of Sweet Maize Crop. Australian Journal of Crop Science, 4, 722-729.

[37] Gemechu, B., Etana, A., Senbeta, F. and Tolossa, D. (2017) Effect of Integrated Farmyard Manure and NP Fertilizers Use on Hybrid Maize Yield and Soil Properties in Western Ethiopia. Net Journal of Agricultural Sciences, 5, 85-93.

https://doi.org/10.30918/NJAS.53.17.036

[38] Wapa, J.M. Kwari, J.D. and Ibrahim, S.A. (2014) Effects of Combining Chemical Fertilizer and Three Different Sources of Organic Manure on the Growth and Yield of Maize in Sub-Sahelian Savanna, Nigeria. Journal of Agriculture and Environmental Sciences, 2, 299-314.

[39] Redda, A. and Kebede, F. (2017) Effects of Integrated Use of Organic and Inorganic Fertilizers on Soil Properties Performance, Using Rice (Oryza sativa L.) as an Indicator Crop in Tselemti District of North-Western Tigray, Ethiopia. International Research Journal of Agricultural Science and Technology, 1, 6-14.

[40] Alim, M.A. (2012) Effect of Organic and Inorganic Sources and Doses of Nitrogen Fertilizer on the Yield of Boro Rice. Journal of Environmental Science and Natural Resources, 5, 273-282. https://doi.org/10.3329/jesnr.v5i1.11592

[41] Gangmei, T.P. and George, P.J. (2017) Black Rice CV. “Chakhao Amubi” (Oryza sativa L.) Response to Organic and Inorganic Sources of Nutrients on Growth, Yield and Grain Protein Content. Journal of Pharmacognosy and Phytochemistry, 6, 550-555.

[42] Chekolle, A.W. (2017) Evaluation of Synergistic Effect Organic and Inorganic Fertilizing System on Grain Yield of Bread Wheat (Triticum aestivum L.) at Southern Tigray, Northern Ethiopia. Advances in Crop Science and Technology, 5, 269. https://doi.org/10.4172/2329-8863.1000269

[43] Agegnehu, G., van Beek, C. and Bird, M.I. (2014) Influence of Integrated Soil Fertility Management in Wheat and Tef Productivity and Soil Chemical Properties in the Highland Tropical Environment. Journal of Soil Science and Plant Nutrition, 14, 532-545.

[44] Abbas, G., Khattak, J., Mir, A., Ishaque, M., Hussain, M., Wahedi, H., Ahmed, M.S and Ullah, A. (2012) Effect of Organic Manures with Recommended Dose of NPK on the Performance of Wheat (Triticum aestivum L.). The Journal of Animal and Plant Sciences, 22, 683-687.

[45] Khan, S. and Khalil, S.K. (2014) Integrated Use of Organic and Inorganic Fertilizers in Wheat and Their Residual Effect on Subsequent Mung Bean. International Journal of Farming and Allied Sciences, 3, 835-844.

[46] Isitekhale, H.H., Osemwota I.O. and Amhakhian, S.O. (2013) Poultry Manure and NPK Fertilizer Application and their Residual Effects on the Yield and Yield Components of Tomato (Lycopersicon esculentum. Mill) in Two Distinct Ecological Zones of Central Southern Nigeria. Journal of Agriculture and Veterinary Science, 3, 40-47. https://doi.org/10.9790/2380-0324047

[47] Charles, O., Haruna, I. and Raphael, O. (2012) Response of Tomato (Lycopersicon esculentum): Growth and Yield, to Rates of Mineral and Poultry Manure Application in the Guinea Savanna Agro-Ecological Zone in Nigeria. Journal of Biology, Agriculture and Healthcare, 2, 44-56.

[48] Khan, A., Bibi, H., Ali, Z., Sharif, M., Shah, S., Ibadullah, H., Khan, K., Azeem, I. and Ali, S. (2017) Effect of Compost and Inorganic Fertilizers on Yield and Quality 
of Tomato. Academia Journal of Agricultural Research, 5, 287-293.

[49] Ogundare, S.K., Babalola, T.S., Hinmikaiye, A.S. and Oloniruha, J.A. (2015) Growth and Fruit Yield of Tomato as influenced by Combined Use of Organic and Inorganic Fertilizer in Kabba, Nigeria. European Journal of Agriculture and Forestry Research, 3, 48-56.

[50] Walia, M.K., Walia, S.S. and Dhaliwal, S.S. (2010) Long Term Effect of Integrated Nutrient Management of Properties of Typic Ustochrept after 23 Cycles of Irrigated Rice (Oriza sativa L.) Wheat (Triticum aestivum L.) System. Journal of Sustainable Agriculture, 34, 724-740. https://doi.org/10.1080/10440046.2010.507519

[51] Salehi, A., Fallah, S. and Sourki, A. (2017) Organic and Inorganic Fertilizer Effect on Soil $\mathrm{CO}_{2}$ Flux, Microbial Biomass, and Growth of Nigella sativa L. International Agrophysics, 31, 103-116. https://doi.org/10.1515/intag-2016-0032 